\title{
Effects of combined midazolam and propofol in anesthesia induction and recovery of cats undergoing ovariohisterectomy
}

\author{
Efeitos do midazolam, associado ao propofol, na indução \\ e recuperação da anestesia em gatas submetidas a \\ ovariossalpingohisterectomia
}

\author{
Diogo Gorayeb de Castro ${ }^{1 *}$; Juliana de Araújo Caldeira ${ }^{1}$; \\ Fernanda Corrêa Devito ${ }^{1}$; Samanta Rios Melo ${ }^{1}$; Silvia Renata Gaido Cortopassi ${ }^{2}$
}

\begin{abstract}
The objective of this study was to determine the effects of propofol and midazolam on induction of anesthesia in cats undergoing ovariohysterectomy, measured in terms of the quality of tracheal intubation, anesthesia induction, cardiorespiratory effects, and recuperation period. Thirty healthy adult cats were pretreated with acepromazine and morphine. After $30 \mathrm{~min}$, they were divided into three groups: PG ( $\mathrm{n}=$ $10)$, in which induction was performed with only intravenous propofol at doses required for intubation; MPG $(\mathrm{n}=8)$, in which animals received intravenous midazolam $\left(0.3 \mathrm{mg} \mathrm{kg}^{-1}\right)$ administered over 30 s, followed by administration of propofol as in PG; and PMG $(n=9)$, in which propofol was first administered at a rate of $4 \mathrm{mg} \mathrm{kg}^{-1} \mathrm{~min}^{-1}$, after which midazolam was administered $(0.3 \mathrm{mg} / \mathrm{kg})$, followed by re-administration of propofol. In order to perform a blinded study, the PG and PMG received a $0.9 \%$ $\mathrm{NaCl}$ solution volume similar to the midazolam dose before induction $(0.06 \mathrm{~mL} / \mathrm{kg})$. Similar to the other groups, the PG and MPG received $\left(0.06 \mathrm{~mL} \mathrm{~kg}^{-1}\right)$ saline $30 \mathrm{~s}$ after administration of propofol. In order to mimic the administration of midazolam, the saline solution was administered for 30s. The PG received $11.0 \pm 1.38 \mathrm{mg} \mathrm{kg}^{-1}$ propofol, a greater dose than that administered to the PMG $(\mathrm{p}<0.001)$ and MPG $(\mathrm{p}<0.01)$, which received $7.9 \pm 1.92$ and $9.1 \pm 2.20 \mathrm{mg} \mathrm{kg}^{-1}$, respectively. There were no differences in the intubation scores between groups. Previous use of midazolam did not affect agitation or excitement in cats; both sequences of propofol-midazolam administration are feasible, but the propofol-midazolam sequence was superior due to the lower propofol dose.
\end{abstract}

Key words: Benzodiazepines, castration, dogs, feline

\section{Resumo}

O objetivo deste estudo foi determinar os efeitos de propofol e midazolam na indução da anestesia em gatas submetidas a ovariossalpingohisterectomia quanto a qualidade da intubação orotraqueal e da indução da anestesia, efeitos cardiorrespiratórios e períodos de recuperação. Foram utilizadas 27 gatas adultas e hígidas que foram pré-tratadas com acepromazina e morfina. Decorridos 30 minutos, foram distribuídas em três grupos: no GP $(\mathrm{n}=10)$, a indução foi realizada somente com propofol por via intravenosa na dose necessária para intubação orotraqueal; no GMP $(\mathrm{n}=8)$, os animais receberam midazolam $(0,3$ $\mathrm{mg} / \mathrm{kg}$ ) administrado pela via intravenosa em $30 \mathrm{~s}$, e em seguida o propofol foi administrado segundo

\footnotetext{
${ }^{1}$ Médicos Veterinários, Discentes de Pós-Graduaçãograduando do Programa de Clínica Cirúrgica Veterinária, Faculdade de Medicina Veterinária e Zootecnia, da Universidade de São Paulo, FMVZ/-USP, São Paulo, SP, Brasil. E-mail: diogo@cesvet. com.br; jucaldeira@gmail.com; fernandadevito@gmail.com; samymelo@usp.br

${ }^{2}$ Prof $^{a}$ Livre-Docente, Departamento de Cirurgia, FMVZ-USP, São Paulo, SP, Brasil. E-mail: silcorto@usp.br

* Author for correspondence
} 
os critérios do grupo propofol; no GPM ( $\mathrm{n}=9$ ), administrou-se, inicialmente, propofol na velocidade de $4 \mathrm{mg} / \mathrm{kg} / \mathrm{min}$; posteriormente, administrou-se midazolam $(0,3 \mathrm{mg} / \mathrm{kg})$, e o restante da indução foi realizado com propofol. Para que o estudo fosse cego, os animais dos grupos GP e GPM receberam solução salina no volume similar à dose de midazolam antes da indução $(0,06 \mathrm{ml} / \mathrm{kg})$. Da mesma forma, os grupos GP e GMP receberam solução de $\mathrm{NaCl}$ a $0,9 \%(0,06 \mathrm{ml} / \mathrm{kg})$ após $30 \mathrm{~s}$ de administração de propofol. Com objetivo de mimetizar a administração do midazolam, a solução salina foi administrada em 30s. O GP recebeu $11,0 \pm 1,38 \mathrm{mg} / \mathrm{kg}$ de propofol, sendo superior a dose dos grupos GPM $(\mathrm{p}<0,001)$

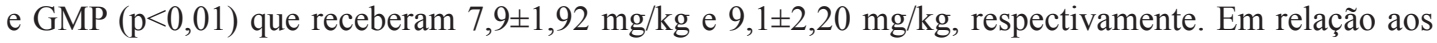
escores de intubação não houve diferença entre os grupos. O uso prévio de midazolam não determinou agitação, tampouco excitação nas gatas; ambas as sequências de administração da associação propofolmidazolam são factíveis, porém a sequência propofol-midazolam se mostrou superior devido a menor dose empregada de propofol.

Palavras-chave: Benzodiazepínicos, cães, castração, felinos

\section{Introduction}

Propofol is widely used to induce anesthesia in cats (SHORT; BUFALARI, 1999; BREARLEY et al., 1988). Derived from alkylphenol, its action is fast and smooth, and it is classified as a shortacting, rapidly metabolized drug (SNEYD, 2004; DUKE, 1995). Due to its phenolic composition, glucuronidation is the main metabolic pathway of its inactivation, which occurs through catalysis of UDP-glucuronyltransferase (UGT) 1.6 isoenzyme (COURT; GREENBLATT, 2000). In cats, this isoenzyme is less frequent or even absent, which makes metabolism of propofol particularly slow (BLEY et al., 2007). Excitatory phenomena, like muscle twitching and opisthotonus (CHATDARONG et al., 2006; COVEY-CRUMP; MURISON, 2008) and decreased respiratory frequency (SELMI et al., 2005; MATTHEWS et al., 2004) have been reported when propofol is used as an anesthesia inductor in cats. Furthermore, repeated dose administration may be associated with a delayed recovery (PASCOE et al., 2006). Thus, coinduction of anesthesia with propofol has been used in order to decrease adverse effects such as apnea, hypotension, and excitation (COVEY-CRUMP; MURISON, 2008; AZARI; CORK, 1993).

The combined use of midazolam and propofol as anesthesia inductors has been studied in humans and dogs, where the greatest advantage of this approach is the reduced propofol dose (HOPKINS et al.,
2014; ADACHI et al., 2001; WILDER-SMITH et al., 2001). Midazolam is a benzodiazepine with anti-convulsive effects; its main feature is the minor induction of cardiac output, making it an ideal anesthesia co-induction agent (OLKKOLA; AHONEN, 2008). In cats and dogs, midazolam can promote excitation and pedal reflex when administered alone (STEGMANN; BESTER, 2001; COVEY-CRUMP; MURISON, 2008; ILKIW et al., 1996). Due to its depressive effects in anesthesia induction, we hypothesized that co-administration of propofol with midazolam could minimize adverse effects. Therefore, the objective of this study was to evaluate the effects of midazolam administered before or after propofol in anesthesia induction in female cats undergoing ovariohysterectomy; we determine these effects by assessing the reduction of propofol dose when it was co-administered with midazolam, the quality of tracheal intubation, anesthesia induction, and recuperation period.

\section{Materials and Methods}

This study was approved by the Bioethics Commission of the Faculty of Veterinary Medicine and Zootechny University of São Paulo under protocol number 1584/2008, and all procedures were authorized by the owners. We used 27 health female adult cats, with weights varying between $2.78 \pm 0.1 \mathrm{~kg}$, classified as American Society of Anesthesiologists (ASA) I, that were undergoing 
ovariohysterectomy. All animals were clinically examined and their blood samples were taken for complete hemogram and testing of hepatic and renal functions.

The animals in this study were pre-treated with acepromazine $\left.(0.1 \mathrm{mg} \mathrm{kg})^{-1}\right)(0.2 \%$ Acepran - Univet - São Paulo, SP, Brazil) and morphine (0.2 mg/kg) (Dimorf - Cristália - São Paulo, SP, Brazil). Next, $5 \mathrm{~mL} \mathrm{~kg}{ }^{-1} \mathrm{~h}^{-1}$ Ringer solution and lactate fluid therapy were administered during the perioperative procedure. Subsequently, the animals were randomly distributed into three groups, and the blind study was performed, with the evaluators (surgeon and anesthetist) unaware of the drugs used as anesthesia inductors: in the propofol group (PG), induction was done using intravenous propofol (Propovan - Cristália, Sâo Paulo, SP, Brazil) at a dosage sufficient for tracheal intubation; the drug was administered with the help of an infusion pump (Digipump SR8X, Davol, São Paulo, SP, Brazil) at a dose of $4 \mathrm{mg} \mathrm{kg}^{-1} \mathrm{~min}^{-1}$, until loss of interdigital and palpebral reflex. Animals in the midazolam-propofol group (MPG) received intravenous midazolam (0.3 $\mathrm{mg} \mathrm{kg}^{-1}$ ) (Dormire - Cristália, São Paulo, SP, Brazil) for $30 \mathrm{~s}$, followed by propofol administered as in the PG; finally, in the propofol-midazolam group (PMG), propofol was initially administered at 4 $\mathrm{mg} \mathrm{kg}{ }^{-1} \mathrm{~min}^{-1}$, midazolam $\left(0.3 \mathrm{mg} \mathrm{kg}{ }^{-1}\right)$ was then administered for $30 \mathrm{~s}$, and the remaining induction was done with propofol until tracheal intubation.

In order to make this a blinded study, animals in the PG and PMG received saline solution at volumes similar the midazolam dose before induction $\left(0.06 \mathrm{~mL} \mathrm{~kg}^{-1}\right)$. Similarly, the PG and MPG received saline solution $\left(0.06 \mathrm{~mL}^{-1} \mathrm{~kg}\right)$ after $30 \mathrm{~s}$ of propofol administration. In order to mimic midazolam administration, the saline solution was administered in $30 \mathrm{~s}$. The drugs were administered by another researcher to prevent the evaluator from knowing the sequence of the induction agents.

Anesthesia induction occurred $30 \mathrm{~min}$ after administration of the pre-anesthetic medication; the loss of interdigital reflex of the left thoracic limb, palpebral reflexes, and mandibular relaxation were used to determine when tracheal intubation could be performed. The animals received general inhalation anesthesia (Shogun - Takaoka, São Paulo, SP, Brazil) with isoflurane (Forane - Abbott, São Paulo, SP, Brazil) diluted in a flux of $500 \mathrm{~mL} \mathrm{~kg} \mathrm{~min}^{-1}$ of $100 \%$ oxygen, through a Mapleson D anesthetic circuit. During the post-operative period, $1 \mathrm{mg}$ $\mathrm{kg}^{-1}$ cetropophen (Ketofen ${ }^{\circledR}$ - Merial, São Paulo, SP, Brazil) and $2 \mathrm{mg} \mathrm{kg}^{-1}$ tramadol (Tramadon ${ }^{\circledR}$ Cristália, São Paulo, SP, Brazil) were administered intravenously 30 minutes before the surgical procedure was completed.

Respiratory and cardiac frequencies were evaluated with a multiparametric monitor (Dash 4000 - GE Healthcare, Helsinki, Finland), systolic pressure was assessed with the help of a vascular Doppler (Model 811-B - Parks Medical Inc., Aloha, USA) using a cuff covering approximately $40 \%$ of the thoracic limb and positioned over the common digital artery; after trichotomy of the area, the average of three measurements was used. These values were verified before and 30 minutes after administration of the pre-anesthetic medication.

The quality of tracheal intubation was assessed by two observers using the following scoring method adapted from Covey-Crump and Murison (2008): 1 - smooth (no swallowing reflex, cough, tongue, or jaw movement); 2 - average (discrete tongue movement and cough); 3 - bad (marked tongue/jaw movement and swallowing reflex or cough); 4 - very bad (same as score 3, but requiring additional propofol and new intubation attempt). During anesthesia induction, the occurrence of excitatory effects such as agitation, muscle twitches, vocalization, and pedal reflex were verified.

The time periods assessed during the postoperative period included time of extubation (period between interruption of inhalation anesthesia and removal of the endotracheal tube when lingual strength was present); ability to maintain head- 
up posture (period between inhalation anesthesia interruption and the moment the animal is able to keep its head up); ability to maintain sternal recumbency (period between interruption of inhalation anesthesia and the moment the animal is able to stay in sternal recumbency); ability to move with moderate ataxia (period between inhalation anesthesia interruption and the moment the animal is able to stay in quadrupedal posture and move, even if moderately ataxic).

The Kolmogorov-Smirnov test was used to assess the normality of the measured values. Animal weights, respiratory and cardiac frequencies, and systolic pressure at the same time points in the three groups and the recovery periods of the different groups were normally distributed; analysis of variance (ANOVA) was done for nonrepetitive measurements, followed by Tukey test. A non-parametric test (Kruskall-Wallis) was used to analyze the non-normally distributed age data.
Student's t-test was used to compare two different periods of observation within the same group. When comparing quality of tracheal intubation between groups, we performed the Friedman test, followed by the Dunn test. Statistical significance was defined as $5 \%(\mathrm{p}<0.05)$. Statistical tests were performed using Graphpad InStat version 3.01 (GraphPad Software, La Jolla California USA).

\section{Results}

All the animals were mixed-breed $((\mathrm{n}=27)$. The average weights of the animals in the $\mathrm{PG}, \mathrm{PMG}$, and MPG were $2.8 \pm 0.5,2.9 \pm 0.66$, and $2.65 \pm$ $0.55 \mathrm{~kg}$, respectively. Their average ages were 19.0 $\pm 16.03,15.5 \pm 12.24$, and $23.9 \pm 27.82$ months, respectively. There was a significant decrease in systolic pressure values after pre-anesthetic medication administration when compared to the base values in all groups (Table 1).

Table 1. Mean values and corresponding standard deviations of cardiac frequency (beats per minute), respiratory frequency (movements per minute), and arterial systolic pressure ( $\mathrm{mmHg}$ ) assessed in the PG (propofol), PMG (propofol/midazolam), and MPG (midazolam/propofol), prior to (basal) and after administration (post) of preanesthetic medication administration (PAM) - São Paulo - 2010.

\begin{tabular}{lccc}
\hline & Groups & \multicolumn{2}{c}{ Moments of assessment } \\
\cline { 2 - 4 } Cardiac frequency & PG & $198 \pm 27.29$ & Post PAM \\
& PMG & $199 \pm 20.03$ & $200 \pm 49.54$ \\
& MPG & $200 \pm 35.87$ & $215 \pm 35.50$ \\
Respiratory frequency & PG & $52 \pm 19.78$ & $211 \pm 47.89$ \\
& PMG & $58 \pm 25.56$ & $42 \pm 12.26$ \\
Arterial systolic pressure & MPG & $57 \pm 37.14$ & $53 \pm 19.42$ \\
& PG & $134 \pm 20.95^{\mathrm{a}}$ & $44 \pm 17.55$ \\
& PMG & $116 \pm 11.32^{\mathrm{b}}$ & $98 \pm 32.92^{\mathrm{a}}$ \\
& $\mathrm{MPG}$ & $128 \pm 12.37^{\mathrm{c}}$ & $86 \pm 16.07^{\mathrm{b}}$ \\
\hline
\end{tabular}

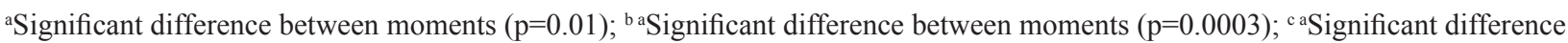
between moments $(\mathrm{p}=0.0045)$.

The propofol doses used to induct anesthesia in the PG, PMG, and MPG were $11.8 \pm 1.64$,
$7.9 \pm 1.92$, and $9.1 \pm 2.3 \mathrm{mg} \mathrm{kg}^{-1}$, respectively. Comparison of the three groups revealed 
significantly higher doses in the PG than in both the PMG $(\mathrm{p}<0.001)$ and MPG $(\mathrm{p}<0.05)$.
There were no significant differences the quality of tracheal intubation as scored by both the anesthetist and the surgeon (Table 2).

Table 2. Examiner (anesthetist and surgeon) intubation scores and standard deviation among PG (propofol), PMG (propofol/midazolam), and MPG (midazolam/propofol), São Paulo - 2010.

\begin{tabular}{cccc}
\hline \multirow{2}{*}{ Examiners } & \multicolumn{3}{c}{ Groups } \\
\cline { 2 - 4 } & GP & PMG & MPG \\
\hline Anesthetist & $1.6 \pm 0.70$ & $1.4 \pm 1.01$ & $1.4 \pm 0.74$ \\
Surgeon & $1.8 \pm 0.92$ & $1.4 \pm 1.01$ & $1.25 \pm 0.46$ \\
\hline
\end{tabular}

Finally, there was no difference in recovery time between groups (Table 3). However, the time periods required for head-up posture, sternal recumbency, and beginning of movement among animals in the PG were lower than those in the PMG $(\mathrm{p}<0.05, \mathrm{p}<$ 0.01 , and $\mathrm{p}<0.05$, respectively) (Table 3 ).

Table 3. Mean values and corresponding standard deviation of periods of anesthesia (minutes) and recovery (extubation, maintenance of head up, sternal recumbency, and movement) among PG (propofol), PMG (propofol/midazolam), and MPG (midazolam/propofol) - São Paulo - 2010.

\begin{tabular}{lccc}
\hline \multicolumn{1}{c}{$\begin{array}{c}\text { Recovery periods } \\
(\mathrm{min})\end{array}$} & \multicolumn{3}{c}{ Groups } \\
\cline { 2 - 4 } & PG & PMG & MPG \\
\hline Period of anesthesia & $66 \pm 13.7$ & $62 \pm 17.7$ & $65 \pm 21.9$ \\
Extubation & $3.3 \pm 2.3$ & $2.7 \pm 1.5$ & $3.1 \pm 2.4$ \\
Head up & $13.7 \pm 6.2^{\mathrm{a}}$ & $24.1 \pm 10.6^{\mathrm{a}}$ & $16.1 \pm 9.2$ \\
Sternal & $15 \pm 5.98^{\mathrm{b}}$ & $31 \pm 12.96^{\mathrm{b}}$ & $20 \pm 8.4$ \\
Movement & $24.2 \pm 11.1^{\mathrm{c}}$ & $37.9 \pm 10.4^{\mathrm{c}}$ & $31.4 \pm 6.7$ \\
\hline
\end{tabular}

a,c Significant difference between PG and PMG $(\mathrm{p}<0.05)$; ${ }^{\mathrm{b}}$ Significant difference between PG and PMG $(\mathrm{p}<0.01)$.

\section{Discussion}

The groups studied were homogenous, with no difference in breeds, weight, or age. Pre-anesthetic administration of acepromazine and morphine caused vomiting in only one animal (3.3\%), different from the $75 \%$ incidence of vomiting in cats pre-treated with morphine reported by Steagall et al. (2006). Co-administration with phenotiazinic reduced the frequency of nausea, probably due to the anti-emetic effect of acepromazine (BREARLEY, 1994).

One of the main objectives of this study was to determine if the propofol dose was reduced when it was administered with midazolam as a co-induction agent during anesthesia. In the PMG, where the animals initially received propofol followed by midazolam, the propofol dosage decreased $33.9 \%\left(11.8 \pm 1.64 \mathrm{mg} \mathrm{kg}^{-1}\right)$; the dosage was also lower in the MPG, where midazolam was administered first $\left(9.1 \pm 2.96 \mathrm{mg} \mathrm{kg}^{-1}\right)$, although the difference was smaller (22.9\%). Bley et al. (2007) also studied anesthesia induction in felines, observing a propofol dosage reduction of $26 \%$ when $0.2 \mathrm{mg} / \mathrm{kg}$ midazolam was administered before induction. The larger reduction in this study was probably due to the use of pre-anesthetic 
midazolam. Recently, Robinson and Borer-Weir (2015) used midazolam $(0.3 \mathrm{mg} / \mathrm{kg})$ after an initial dose of propofol $\left(2 \mathrm{mg} \mathrm{kg}^{-1}\right)$ and observed a $37.5 \%$ reduction in the total inductor dose. Although the midazolam and propofol dosages used in the current study were similar $\left(0.3 \mathrm{mg} \mathrm{kg}^{-1}\right.$ and $2 \mathrm{mg}$ $\mathrm{kg}^{-1} \mathrm{~min}^{-1}$, respectively) to the above study, the reduction of propofol dosage in our study was smaller $(33.9 \%)$, probably because higid animals were analyzed in our study, while 69\% were ASA II in the Robinson and Boren-Weir study (ROBINSON; BORER-WEIR, 2015). Moreover, their animals were sedated with $0.01 \mathrm{mg} \mathrm{kg}^{-1}$ acepromazine and $0.3 \mathrm{mg} \mathrm{kg}{ }^{-1}$ methadone, which might have resulted in greater sedation than the acepromazine and morphine protocol used in our study. This hypothesis is based on the use of nonhigid animals; however, since sedation scores were not used in the current study, it cannot be confirmed.

Findings differ among studies in dogs. Ko et al. (2006) reported a propofol dosage reduction of $36 \%$ and $21 \%$ with $0.4 \mathrm{mg} \mathrm{kg}^{-1}$ and $0.2 \mathrm{mg} \mathrm{kg}^{-1}$ diazepam, respectively. Hopkins et al. (2014) also observed a decrease in propofol dosage (34\%) when $0.2 \mathrm{mg} \mathrm{kg}^{-1}$ midazolam was administered. However, Covey-Crump and Murison (2008) did not observe a significant reduction in propofol dosage when $0.2 \mathrm{mg} \mathrm{kg}^{-1}$ midazolam was administered before anesthetic induction. Both studies administered similar pre-anesthetic medications, but CoveyCrump and Murison (2008) administered propofol only two minutes after midazolam, while Hopkins et al. (2014), administered propofol immediately after midazolam. These differences in midazolam administration might explain the contrasting results. Another probable explanation for these differences is the rate of propofol administration, which directly affects the induction dose (SHORT; BUFALARI, 1999; MENDES et al., 2003; TABOADA; MURISON, 2010). Studies comparing dosages did not describe the rate of administration (BREARLEY el al., 1988; MORGAN; LEGGE,
1989; WEAVER; RAPTOPOULOS，1990). The current study administered drugs at $4 \mathrm{mg} \mathrm{kg}^{-1} \mathrm{~min}^{-1}$, as reported by Covey-Crump and Murison (2008) for anesthesia induction in dogs. Taboada and Murison (2010) reported an average induction dose of $7.5 \mathrm{mg} \mathrm{kg}^{-1}$ when administered at a rate of $6 \mathrm{mg}$ $\mathrm{kg}^{-1} \mathrm{~min}^{-1}$ for anesthesia induction in cats that were not pre-medicated.

Additionally, both Hopkins et al. (2014) and Covey-Crump and Murrison (2008) reported excitation in dogs during intravenous administration of midazolam. The literature has postulated that agitation may be associated with disinhibition effects caused by benzodiazepines, leading to behavior alterations like ataxia, sound hypersensibility, intense salivation, and muscular weakness (GARDOS, 1980; ADAMS et al., 1985; COURT; GREENBLATT, 2000). In a study by Robinson and Borer-Weir (2015) 2.5\% of the animals presented slight myoclonia after administration of $2 \mathrm{mg} \mathrm{kg}^{-1}$ propofol followed by a bolus dose of $0.3 \mathrm{mg} \mathrm{kg}^{-1}$ midazolam or diazepam (ROBINSON; BORER-WEIR, 2015). In the present study, no episodes of excitation or myoclonia were observed.

The use of PAM may have contributed to the propofol doses in the current study. Generally, 5-10 $\mathrm{mg} \mathrm{kg}{ }^{-1}$ propofol is used to induce anesthesia in cats that receive PAM with acepromazine $(0.1 \mathrm{mg} \mathrm{kg}$ $\left.{ }^{1}\right)$ and morphine $\left(0.2 \mathrm{mg} \mathrm{kg}^{-1}\right)$ (BREARLEY et al., 1988; EGGER et al., 2009); however, other authors have reported lower doses $\left(2-3 \mathrm{mg} \mathrm{kg}^{-1}\right)$ when using medetomidine $\left(20 \mu \mathrm{g} \mathrm{kg}^{-1}\right)$ and butorphanol (0.4 $\left.\mathrm{mg} \mathrm{kg}^{-1}\right)$ as PAM (SLINGSBY et al., 2014).

Use of midazolam did not affect tracheal intubation, since the quality was similar in the groups (smooth to regular). However, both PMG and MPG presented better quality of tracheal intubation, with seven of 10 cats receiving a smooth score compared to five of 10 cats in the control group (PG). This result contrasts with findings reported by Hopkins et al. (2014), in which $100 \%$ of dogs in the PG 
had smooth induction quality scores, compared to $55.56 \%$ in the PMG.

\section{Conclusions}

Midazolam used as co-induction agent in cats reduced the required dosage of propofol by up to $33.9 \%$, and the induction was calm and excitationfree. The use of midazolam prior to propofol to induce anesthesia did not cause agitation or excitation in the female cats; both sequences of propofol-midazolam administration are feasible, however, the sequence propofol-midazolam has proven superior due to the decreased propofol dose.

\section{References}

ADACHI, Y. U.; WATANABE, K.; HIGUCHI, H.; SATOH, T. A small dose of midazolam decreases the time to achieve hypnosis without delaying emergence during short-term propofol anesthesia. Journal of Clinical Anesthesia, Stoneham, v. 13, n. 4, p. 277-280, 2001.

ADAMS, P.; GELMAN, S.; REVES, J. G.; GREENBLATT, D. J.; ALVIS, J. M.; BRADLEY, E. Midazolam pharmacodynamics and pharmacokinetics during acute hypovolemia. Anesthesiology, Phiiladelfia, v. 63 , n. 2 , p. $140-146,1985$.

AZARI, D. M.; CORK, R. C. Comparative myocardial depressive effects of propofol and thiopental. Anesthesia Analgesia, Baltimore, v. 77, n. 2, p. 324-329, 1993.

BLEY, C. R.; ROSS, M.; PRICE, J. Clinical assessment of repeated propofol-associated anesthesia in cats. Journal of the American Veterinary Medical Association, Ithaca, v. 231, n. 9, p. 1347-1353, 2007.

BREARLEY, J. C. Sedation, premedication and analgesia. In: HALL, L. W.; TAYLOR, P. M. Anaesthesia of the cat. London: Baillière Tindall, 1994. p. 111-128.

BREARLEY, J. C.; KELlAGHER, R. E.; HALL, L. W. Propofol anesthesia in cats. Journal of Small Animal Practice, Oxford, v. 29, n. 5, p. 315-322, 1988.

CHATDARONG, K.; PONGLOWHAPAN, S.; MANEE-IN, S.; PONGPHET, K. The use of propofol for electroejaculation in domestic cats. Theriogenology, Philadelphia, v. 66, n. 6-7, p. 1615-1617, 2006.
COURT, M. H.; GREENBLATT, D. J. Molecular genetic basis for deficient acetaminophen glucuronidation by cats: UGT1A6 is a pseudogene, and evidence for reduced diversity of expressed hepatic UGT1 isoforms. Pharmacogenetics, London, v. 10, n. 4, p. 355-396, 2000.

COVEY-CRUMP, G. L.; MURISON, P. J. Fentanyl or midazolam for co-induction for anesthesia with propofol in dogs. Veterinary Anaesthesia and Analgesia, Oxford, v. 35, n. 6, p. 463-472, 2008.

DUKE, T. A new intravenous anesthetic agent: propofol. The Canadian Veterinary Journal, Guelph, v. 36, n. 3, p. 181-183, 1995.

EGGER, C.; MCCRACKIN, M. A.; HOFMEISTER, E.; TOUZOT-JOURDE, G.; ROHRBACH, B. Efficacy of preanesthetic intramuscular administration of ephedrine for prevention of anesthesia-induced hypotension in cats and dogs. The Canadian Veterinary Journal, Guelph, v. 50, n. 2, p. 179-184, 2009.

GARDOS, G. Disinhibition of behavior by antianxiety drugs. Psychosomatics, Washington, v. 21, n. 12, p. 1025-1026, 1980.

HOPKINS, A.; GIUFFRIDA, M.; LARENZA, M. P. Midazolam, as a co-induction agent, has propofol sparing effects but also decreases systolic blood pressure in healthy dogs. Veterinary Anaesthesia and Analgesia, Oxford, v. 41, n. 1, p. 64-72, 2014.

ILKIW, J. E.; SUTER, C. M.; FARVER, T. B.; McNEAL, D.; STEFFEY, E. P. The behaviour of healthy awake cats following intravenous and intramuscular administration of midazolam. Journal of Veterinary Pharmacology and Therapeutics, Oxford, v. 19, n. 3, p. 205-216, 1996.

KO, J. C. H.; PAYTON, M. E.; WHITE, A. G. Effects of intravenous diazepam or microdose medetomidine on propofol-induced sedation in dogs. Journal of the American Animal Hospital Association, Lakewood, v. 42, n. 1, p. 18-27, 2006.

MATTHEWS, N. S.; BROWN, R. M.; BARLING, K. S.; LOVERING, S. L.; HERRIG, B. W. Repetitive propofol administration in dogs and cats. Journal of the American Animal Hospital, Lakewood, v. 40, n. 4, p. 255-260, 2004.

MENDES, G. M.; SELMI, A. L.; BARBUDO-SELMI, G. R.; LINS, B. T.; FIGUEIREDO, J. P. Clinical use of dexmedetomidine as premedicant in cats undergoing propofol-sevoflurane anesthesia. Journal of Feline Medicine and Surgery, v. 5, n. 5, p. 265-270, 2003.

MORGAN, D. W. T.; LEGGE, K. Clinical evaluation of propofol as an intravenous anesthetic agent in cats and dogs. Veterinary Record, London, v. 124, n. 2, p. 31-33, 1989. 
OLKKOLA, K. T.; AHONEN, J. Midazolam and other benzodiazepines. Handbook of Experimental Pharmacology, v. 182, p. 335-360, 2008.

PASCOE, P. J.; ILKIW, J. E.; FRISCHMEYER, K. J. The effect of the duration of propofol administration on recovery from anesthesia in cats. Veterinary Anaesthesia and Analgesia, Oxford, v. 33, n. 1, p. 2-7, 2006.

ROBINSON, R.; BORER-WEIR, K. The effects of diazepam or midazolam on the dose of propofol required to induce anaesthesia in cats. Veterinary Anaesthesia and Analgesia, Oxford, v. 42, n. 5, p. 493-501, fev. 2015.

SELMI, A. L.; MENDES, G. M.; LINS, B. T.; FIGUEIREDO, J. P.; BARBUDO-SELMI, G. R. Comparison of xylazine and medetomidine as premedicants for cats being anaesthetized with propofolsevoflurane. Veterinary Record, London, v. 157, n. 5, p. 139-143, 2005.

SHORT, C. E.; BUFALARI, A. Propofol anesthesia. The Veterinary Clinics of North American. Small Animal Practice, Philadelphia, v. 29, n. 3, p. 747-778, 1999.

SLINGSBY, L. S.; BORTOLANI, E.; MURRELL, J. C. Methadone in combination with medetomidine as premedication prior to ovariohysterectomy and castration in the cat. Journal of Feline and Medicine and Surgery, London, v. 17, n. 10, p. 864-872, nov. 2014
SNEYD, J. R. Recent advances in intravenous anaesthesia. British Journal of Anaesthesia, London, v. 93, n. 5, p. 725-736, 2004.

STEAGALL, P. V. M.; CARNICELLI, P.; TAYLOR, P. M.; LUNA, S. P. L.; DIXON, M. J.; FERREIRA, T. H. Effects of subcutaneous methadone, morphine, buprenorphine, or saline on thermal and pressure thresholds in cats. Journal of Veterinary Pharmacology and Therapeutics, Oxford, v. 29, n. 6, p. 531-537, 2006.

STEGMANN, G. F.; BESTER, L. Some clinical effects of midazolam premedication in propofol-induced and isoflurane-maintained anaesthesia in dogs during ovariohysterectomy. Journal of South Africa Veterinary Association, Pretoria, v. 72, n. 4, p. 214-216, 2001.

TABOADA, F. M.; MURISON, P. J. Induction of anesthesia in dogs with alfaxalone or propofol before isoflurane maintenance in cats. Veterinary Record, London, v. 167, n. 3, p. 85-89, 2010.

WEAVE, B. M.; RAPTOPOULOS, D. Induction of anaesthesia in dogs and cats with propofol. Veterinary Record, London, v. 23, n. 126, p. 617-620, 1990.

WILDER-SMITH, O. H. G.; RAVUSSIN, P. A.; DECOSTERD, L. A.; DESPLAND, P. A.; BISSONNETTE, B. Midazolam premedication reduces propofol dose requirements for multiple anesthetic endpoints. Canadian Journal of Anaesthesia, Toronto, v. 48, n. 5, p. 439-445, 2001. 